Research Article

\title{
Optimization of Parameters Using Response Surface Methodology to Develop a Novel Kefir-Like Functional Beverage from Cheese Whey Enriched with Myrtle Juice
}

\author{
Sana M'hir $\mathbb{D}^{1,2}$ Asma Mejri ${ }^{10},{ }^{1}$ Hajer Atrous, ${ }^{1}$ and Lamia Ayed $\mathbb{D}^{1}$ \\ ${ }^{1}$ Laboratory of Microbial Ecology and Technology (LETMI), National Institute of Applied Sciences and Technology (INSAT), \\ University of Carthage, BP: 676. 1080, Tunis, Tunisia \\ ${ }^{2}$ Department of Animal Biotechnology, Higher Institute of Biotechnology of Beja, University of Jendouba, 9000, BP: 382, \\ Beja 9000, Tunisia \\ Correspondence should be addressed to Sana M’hir; sana2617@yahoo.fr
}

Received 7 August 2021; Revised 17 October 2021; Accepted 18 October 2021; Published 12 November 2021

Academic Editor: Ramon Gerardo Guevara-González

Copyright (c) 2021 Sana M’hir et al. This is an open access article distributed under the Creative Commons Attribution License, which permits unrestricted use, distribution, and reproduction in any medium, provided the original work is properly cited.

\begin{abstract}
Whey, liquid wastewater from cheese production, is one of the sources of dietary protein and lactose that are still largely unused for human consumption. It is only in recent years that it has aroused the interest of industries and sought as a valuable raw material and thus represents an opportunity for the manufacture of new products. The manufacture of fermented whey drink requires the mixing of whey with fruit juice or an aromatic plant to improve its organoleptic properties and acceptability. Myrtle, an aromatic medicinal plant, known for its health benefits is not well exploited for making dairy products. This is the first report on the development of kefir-myrtle beverage. Three factors were optimized (whey permeates (\%), myrtle's juice (\%), and kefir grains as inoculum (\%)) using a central composite design with response surface methodology. The analyses showed that the number of lactic acid bacteria (LAB) and yeast cells varied from 5.4 to $9.2 \log _{10} \mathrm{CFU} / \mathrm{mL}$ and from 4.3 to $6.2 \log _{10} \mathrm{CFU} / \mathrm{mL}$, respectively. A decrease in $\mathrm{pH}$ and an increase in the total polyphenol content and antioxidant activity were observed. The analysis of variance indicated the goodness of fit of the model with $R^{2}$ from 0.827 to 0.966 . The absolute average deviation values of each model were low and ranged from $1.61 \%$ to $4.23 \%$. The optimized fermented kefir whey beverage accomplished an overall acceptability of 5.41 ( 1 to 9 preference scale) and a high number of LAB cells $\left(8.53 \log _{10} \mathrm{CFU} / \mathrm{mL}\right)$. The viability of LAB and yeast cell was maintained at 7.61 and $6.19 \log _{10} \mathrm{CFU} / \mathrm{mL}$, respectively, after 14 days of storage.
\end{abstract}

\section{Introduction}

The dairy industry in Tunisia is one of the important food industries in the country. This sector comprises 25 enterprises that processed daily about 3.8 million liters, and $13 \%$ of the total volume of produced milk is destined for cheese production [1]. In the past, whey was considered a byproduct, but now it is considered a coproduct. Its valorization is both an economic and ecological issue since it has a high chemical oxygen demand (COD) [2]. Indeed, when whey is discharged into rivers, it generates eutrophication problem and toxicity modifying the physicochemical properties of aquatic ecosystems [3].
The relatively new interest in this byproduct results mainly from its composition rich in proteins, lactose, and water-soluble vitamins and minerals. Furthermore, it represents a well-balanced source of essential amino acids [4].

There are different processes to value whey. Among the most used technologies are drying, evaporation, reverse osmosis, nanofiltration, and ultrafiltration. By its biochemical composition, whey can be also considered an excellent culture medium for microorganisms.

Since lactose is the main component of whey solids, various biotechnological processes have been developed to use whey as a substrate to produce important industrial products having functional properties. For example, it can be 
converted into prebiotic such as galactooligosaccharides (GOS), lactulose, lactobionic acid, and tagatose [5]. In addition, lactic acid fermentation of whey makes it rich in GOS [6], which exerts a stimulating effect on the growth of probiotic bacteria [5]. Bioactive peptides manifesting antihypertensive, antioxidant, immunomodulatory, and antimicrobial activities can also be released during fermentation [7].

On the other hand, lactic acid fermentation was known as an important tool to increase the bioavailability of polyphenols in food. To date, kefir grains were largely exploited for dairy and nondairy beverages fermentation. Numerous studies described the health benefits of kefir including antihypertensive, antidiabetic, anti-inflammatory, anticancer, antioxidative, and antihypercholesterolemic properties reviewed by Azizi et al. [8]. These therapeutic's aspects made kefir a suitable proposal for commercial intention.

However, to improve whey fermented beverages' flavor and increase their consumption among young people, they should be mixed with fruits juice [9-12]. In fact, fruit and vegetables are rich in nutrients and phytochemicals such as vitamins, minerals, and phenolic compounds [13]. Due to their various micronutrients, fruits and vegetables are often considered as "functional foods" helping to prevent various diseases such as cancer, obesity, and diabetes [14].

Myrtus communis L. is an aromatic and medicinal plant belonging to the family of Myrtaceae. It is widespread in the Mediterranean regions, such as North Africa and Southern Europe, and also found in South America, Australia, and in some areas of the Himalaya [15]. Myrtle berries have a long history of application in the pharmaceutical and food industries. They contain many biologically active compounds such as phenolic compounds, flavonoids, and anthocyanins [16], which are thought to be responsible for their antioxidant proprieties. They also have various positive effects on human health, and they are used as antiseptic, analgesic, cardiotonic, diuretic, anti-inflammatory, stomachic, nephroprotective, antidote, hemostatic, brain tonic, and antidiabetic properties [16].

Experimental designs can be used as a method for formulating food products. They allow selecting the factors that influence the response, modeling the variations in the system response according to the fluctuations of the factors, and validating experimentally the model described by a mathematical equation. However, a suitable range for each factor is also an important consideration for the accuracy of the final model [17-19].

The aim of this study is to optimize the formula of a functional whey beverage. Optimization was done by a central composite design (CCD) to determine the optimum ratio of whey permeate, myrtle juice, and kefir inoculum on $\mathrm{pH}$, lactic acid bacteria (LAB), and yeast viability, \% radical scavenging activity, polyphenol content, and overall acceptability. From this design, the surface plots of considered responses with respective second-order polynomial models were obtained. Finally, the analysis of variance (ANOVA) was employed to judge the adequacy of the model, and the optimized formulation was validated experimentally.

\section{Materials and Methods}

2.1. Kefir Grains and Raw Material. Kefir grains (KG) used in this study were collected from Tunisian households and preserved by the laboratory of microbial ecology and microbial technology (LETMi, INSAT) [11, 20]. The grains were cultured in sterile cow milk and renewed daily to maintain their viability. Kefir grain is polysaccharides and protein matrixes consisting of a symbiotic community were LAB $\left(10^{8} \mathrm{CFU} / \mathrm{g}\right)$ and yeasts $\left(10^{5} \mathrm{CFU} / \mathrm{g}\right)$. The predominant $\mathrm{LAB}$ in the used grains are related to Leuconostoc spp., Lactobacillus spp., and Lactococcus spp. Saccharomyces spp. and Zygosaccharomyces spp. are the dominant yeasts [21]. Kefir grains produce $0.6 \%$ lactic acid titratable acidity.

Cheese whey was collected from an artisanal cheese maker, and whey permeate was provided by dairy industry. The composition of liquid cheese whey was lactose $5.01 \%$ (w/ $\mathrm{v})$, proteins $1.22 \%(\mathrm{w} / \mathrm{v})$, fat $0.34 \%(\mathrm{w} / \mathrm{v})$, and ash $0.8 \%(\mathrm{w} / \mathrm{v})$. Whey permeate contains lactose $85 \%(\mathrm{w} / \mathrm{v})$, proteins $3 \%(\mathrm{w} /$ $\mathrm{v})$, and ash $7 \%(\mathrm{w} / \mathrm{v})$.

Lactose, total proteins, the total fat content, and the ash were determined using the HPLC method [22], the Kjeldahl method [23], and a solvent extraction [24] and by heating the samples at $550^{\circ} \mathrm{C}$ [25], respectively. The $\mathrm{pH}$ of the beverages was measured using a $\mathrm{pH}$ meter (Mettler-Toledo EL20).

Myrtle fruits (Myrtus communis) were collected from the area of Nefza (north-west of Tunisia, latitude $36^{\circ} 58^{\prime} 31^{\prime \prime} \mathrm{N}$, longitude $9^{\circ} 04^{\prime} 51^{\prime \prime} \mathrm{E}$, altitude $500 \mathrm{~m}$, far $147 \mathrm{~km}$ from Tunis, the capital), purchased from the local market in January 2019. The berries were washed and crushed with a mixer by adding distilled water $\left(8^{\circ} \mathrm{Brix}\right)$. The mixture was filtered to obtain a juice that was pasteurized at $70^{\circ} \mathrm{C}$ for $15 \mathrm{~min}$ and used immediately.

\subsection{Beverage Formulation Using a Response Surface Meth-} odology (RSM). The solution of cheese whey and whey permeate were sterilized for $20 \mathrm{~min}$ at $120^{\circ} \mathrm{C}$ and then mixed with myrtle juice according to the plan of RSM. Obtained beverages $(400 \mathrm{~mL})$ were placed in bottles and inoculated with kefir grains (Figure 1).

Central composite design (CCD) was used to develop a novel kefir-like functional beverage from cheese whey enriched by myrtle juice (MJ). The RSM is a combination of experiment design, statistics, empirical modeling, and mathematical optimization techniques. The number of experiments to be carried out was determined rationally, which avoids redundancies of information. In addition, the implementation of an optimization procedure allows the study of the interactions between the different factors. It is possible that a factor that apparently has no effect on the phenomenon being studied and influences this phenomenon indirectly through an interaction. The construction of the response surfaces is carried out following the adjustment of the model using mathematical functions such as polynomials [26].

The central composite design used for the developing of whey kefir-like beverage consists of nineteen experiments 


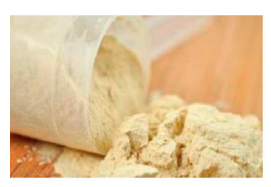

Whey permeate

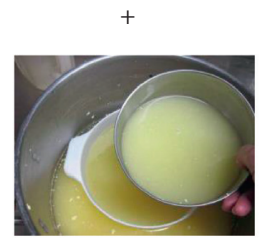

Cheese whey $+$

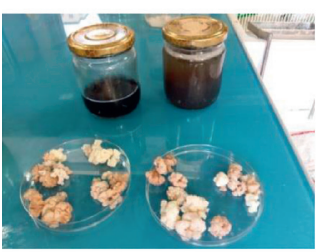

Myrtle juice and Kefir grains
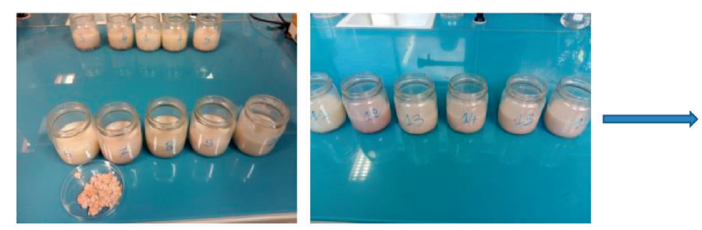

Formulation with central composite design

Responses:

- LAB count,

- Yeast count,

- Antioxidant activities,

- Total polyphenol content,

- Sensorial analysis

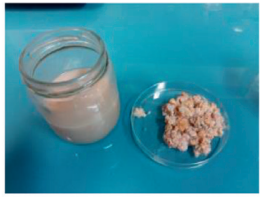

Optimized fermented kefir beverage

FIGURE 1: Whey valorization by developing a kefir-like functional beverage from cheese whey, whey permeate, and myrtle juice.

with five replicates at the central points. The independent variables (whey permeate X1, myrtle juice X2, and kefir grains inoculum $\mathrm{X} 3$ ) in the design were assigned into five levels, coded $-1.68,-1,0,1$, and 1.68 as described in Table 1 . The responses were $\mathrm{pH}$, lactic acid bacteria viability, yeast viability, total polyphenol content (TPC), antioxidant capacity (DPPH), and overall acceptability (OA). The results obtained from the CCD were used to fit a second-order polynomial equation:

$$
\begin{aligned}
Y= & b_{0}+b_{1} X_{1}+b_{2} X_{2}+b_{3} X_{3}+b_{11} X_{1}^{2}+b 22 X_{2}^{2} \\
& +b_{33} X_{3}^{2}+b_{12} X_{1} X_{2}+b_{13} X_{1} X_{3}+b_{23} X_{2} X_{3}
\end{aligned}
$$

where $Y$ is the predicted response; $X_{1}, X_{2}$, and $X_{3}$ are the independent variables; $b_{0}$ the model constant; $b_{1}, b_{2}$, and $b_{3}$ are the linear effect of variables; $b_{11}, b_{22}$, and $b_{33}$ are the squared effect of variables; and $b_{12}, b_{13}$, and $b_{23}$ are the interaction effect of variables. These coefficients were calculated using software NEMROD-W (version 99901, LPRAI Company).

2.3. Lactic and Yeast Counts. Lactic acid bacteria and yeasts were quantified using conventional culture techniques [27]. $\mathrm{LAB}$ were quantified on MRS agar (with cycloheximide $150 \mu \mathrm{g} / \mathrm{mL}$ ) and yeasts on PDA supplemented with chloramphenicol $(100 \mathrm{mg} / \mathrm{L})$; they were incubated at $37^{\circ} \mathrm{C}$ and $30^{\circ} \mathrm{C}$ for $48 \mathrm{~h}$, respectively. The results were expressed as $\mathrm{CFU} / \mathrm{mL}$. The numbers of $\mathrm{LAB}$ and yeasts were converted to $\log \mathrm{CFU} / \mathrm{mL}$.
2.4. Polyphenol Content and Free Radical Scavenging Capacity (DPPH Assay). The TPC was determined following the method of Folin-Ciocalteau [28], modified by Karaaslan et al. [29]. The mixture of each beverage $(0.03 \mathrm{~mL})$ and distilled water $(2.730 \mathrm{~mL})$ was added to the Folin-Ciocalteau reagent $(0.15 \mathrm{~mL})$. After adding sodium carbonate $(20 \%)$, the mixture was left at room temperature for $30 \mathrm{~min}$. The absorbance was measured at $750 \mathrm{~nm}$ (Jenway $63200 \mathrm{UV} / \mathrm{Vis}$ ). The TPC was expressed as mg of gallic acid equivalent $/ \mathrm{mL}$ of the sample. The correlation coefficient was $R^{2}=0.991$.

The free radical scavenging activity of the samples was determined using DPPH (1,1-diphenyl-2-picrylhydrazyl) method according to the method proposed by Balakrishnan and Agrawal with some modifications [30]. Each sample $(700 \mu \mathrm{L})$ was added to $700 \mu \mathrm{L}$ DPPH methanolic solution $(0.035 \mathrm{~mol} / \mathrm{L})$. The mixture was shaken and allowed to stand at room temperature for $30 \mathrm{~min}$. Antioxidant capacity was measured by recording the absorbance at $517 \mathrm{~nm}$ using a spectrophotometer (Jenway 63200 UV/Vis). Methanol was used as the blank. All the determinations were performed in triplicate. A mixture of DPPH solution and methanol (instead of the sample) was used as the negative control for this assay. Percentage of DPPH radical scavenging activity was the result of antioxidant activity. The scavenging activity was calculated by the following equation:

DPPH scavenging activity $(\%)=\frac{(A(\text { control })-A(\text { sample }))}{A(\text { control })}$ $\times 100$. 
TABLE 1: Experimental range and levels of the three factors used in the central composite design for beverage formulation.

\begin{tabular}{lccc}
\hline Level & & Independent variables & \\
& $X_{1}$ (whey permeate fortification, \% w/v) & $X_{2}$ (fruit juice, \% w/v) & $X_{3}(\mathrm{kefir}$ grains, \% w/v) \\
\hline+1.68 & 5 & 50 & 5 \\
+1 & 4 & 42 & 4.4 \\
0 & 2.5 & 30 & 3.5 \\
-1 & 1 & 18 & 2.6 \\
-1.68 & 0 & 10 & 2 \\
\hline
\end{tabular}

2.5. Sensory Evaluation. A total of 40 persons have contributed to a panel test; they were from the food technology department and the dairy industry (students and staff, ranging 24-56 ages). The evaluation was based on the hedonic sensory acceptance of beverage samples using a 9point hedonic scale. The drinking water was given to tasters to rinse their mouth between each sample. Beverages were evaluated for color, odor, sweetness, acidity, taste, and overall acceptability [31].

2.6. Statistical Analysis. All experiments were carried out in triplicate. All data are reported as the mean \pm standard deviation. Statistics were performed with the analysis of variance (ANOVA) procedure (STATIGRAPHICS 202 Centurion XVI software, Statpoint Technologies, Warrenton, USA). Differences were considered significant at $p<0.05$.

\section{Results and Discussion}

Whey-based milk drinks can sometimes have unpleasant flavors. The improvement of their organoleptic characteristics can be obtained by the addition of fruit concentrates and/or by fermentation. To obtain a novel kefir-like functional beverage, the whey was fortified by WP, and myrtle juice was then fermented by kefir grains. The effects of whey permeate; myrtle juice and kefir grains' levels on the nutritional and organoleptic characteristics of the obtained beverages were investigated using a CCD. These independent variables (WP $\left(X_{1}\right)$, fruit juice $\left(X_{2}\right)$, and percentage of inoculum $\left(X_{3}\right)$ levels) were prescribed into five levels $(-1.68$, $-1,0,+1$, and +1.68$)$. Tables 2 and 3 present the experimental values of total polyphenol content (mg EGA/mL), radical scavenging activity, $\mathrm{LAB}$ and yeasts' viability, $\mathrm{pH}$, and sensory evaluation for each run of the CCD. Results from the 19 runs were fitted to a second-order polynomial equation, and the removal of nonsignificant terms was assigned. When the values of $R^{2}$ and $R^{2}$ adj. are close to 1 , the results indicate the adequacy of the fitted models. Yaakob et al. [32] mentioned that $R^{2}$ should be at least $80 \%$ and Cruz et al. [33] reported that the values of $R^{2}$ adj. should be over $70 \%$. However, the calculation of $R^{2}$ and absolute average deviation values (AAD) together should be better to determine the accuracy of the model. $R^{2}$ must be close to 1.0 , and the AAD between the predicted and observed data must be as small as possible [34]. AAD values of six predicted models were calculated; they were $4.23 \%$ for TPC, $1.61 \%$ for antioxidant activities, $2.75 \%$ for LAB number, $1.96 \%$ for yeasts counts, $2 \%$ for $\mathrm{pH}$, and $4.13 \%$ for overall acceptability.
Therefore, the model illustrates the global variability; it is predictive (Supplementary Materials (available here)).

\subsection{Effects of the Variables on Total Phenolic Content and} Antioxidant Activity. Myrtle is considered a preventive element against diseases related to oxidative stress. Indeed, it is rich in many chemical compounds including phenolic compounds and essential oils [35]. Many groups of phenolics were identified such as phenolic acids, hydrolyzable tannins (gallotannins), flavonoids, and anthocyanins [36]. Messaoud and Boussaid [37] reported that their antioxidant activities are due to their phenolic compounds. The TPC values of obtained beverages varied from $55.25 \pm 0.68$ to $90.45 \pm 0.07 \mathrm{mg} \mathrm{EGA} / \mathrm{mL}$, and the $\mathrm{DPPH}$ radical scavenging from $65.25 \pm 0.22$ to $91.6 \pm 0.29 \%$ (Table 2 ). $R^{2}$ and adj $R^{2}$ for TPC and DPPH radical scavenging activity are close to 1 . The AAD values were $4.23 \%$ and $1.61 \%$, respectively.

An increase in myrtle juice or whey permeate or kefir inoculum level improves the TPC and DPPH radical scavenging activity $(p<0.001$; Table 4$)$. It must be mentioned that a $p$ value lower than 0.001 showed that the model is highly significant in the response. The coefficients for linear and quadratic models are also highly significant $(p<0.01$; Table 4$)$. The highest level of TPC and DPPH radical scavenging activity was obtained with 5.08\% WP, 50.59 fruit juice $(\% \mathrm{w} / \mathrm{v})$, and $5.04 \%$ inoculums (Figures 2 and 3).

With regard to interaction, myrtle juice and kefir inoculum's level affect positively the TPC and the antioxidant activity. These results could be due to the metabolic activities of microorganisms in kefir grains. In fact, microbial enzymes break down polyphenol compounds and form aglycones [38]. These latter can be also liberated from their corresponding glycosides, contributing to enhancing the bioavailability of polyphenol [39] and increasing their quantitative amount [40, 41]. Sabokbar et al. [42] showed that the addition of kefir to apple juice enhanced both the total phenolic content and antioxidant activities. During the last years, several works have been interested in the action of lactic acid bacteria and kefir microflora on phenolic compounds [43-46]; they cited many enzymes, which are involved in the hydrolysis mechanisms and which are inducible as a specific stress response.

The improvement of the antioxidant activity after fermentation (Table 5) is in line with other studies [11, 47-51]. The increase of DPPH radical scavenging of fermented beverages indicated that fermentation may produce metabolites with higher and better antioxidant activity. The release of bioaccessible phenolic compounds can be one of 
TABLE 2: Matrix of the central composite design for three variables and the measured responses (DPPH scavenging activity and total phenolic content).

\begin{tabular}{|c|c|c|c|c|c|}
\hline \multirow[b]{2}{*}{ Run } & \multicolumn{3}{|c|}{ Independent variables } & \multicolumn{2}{|c|}{ Response variables } \\
\hline & $X_{1}($ whey permeate, $\% \mathrm{w} / \mathrm{v})$ & $X_{2}($ myrte juice, \% w/v) & $X_{3}($ kefir grains, $\% \mathrm{w} / \mathrm{v})$ & $\begin{array}{l}\text { DPPH scavenging } \\
\text { activity (\%) }\end{array}$ & $\begin{array}{c}\text { Total phenolic } \\
\text { content }(\mathrm{mg} \mathrm{EGA} / \mathrm{mL})\end{array}$ \\
\hline 1 & 1.0 & 18 & 2.6 & $68.40 \pm 0.61$ & $57.58 \pm 0.28$ \\
\hline 2 & 4.0 & 18 & 2.6 & $72.60 \pm 0.26$ & $59.75 \pm 0.42$ \\
\hline 3 & 1.0 & 42 & 2.6 & $71.25 \pm 0.36$ & $64.80 \pm 0.49$ \\
\hline 4 & 4.0 & 42 & 2.6 & $75.60 \pm 0.26$ & $63.60 \pm 1.04$ \\
\hline 5 & 1.0 & 18 & 4.4 & $70.80 \pm 0.06$ & $69.97 \pm 0.08$ \\
\hline 6 & 4.0 & 18 & 4.4 & $73.60 \pm 0.30$ & $70.68 \pm 0.29$ \\
\hline 7 & 1.0 & 42 & 4.4 & $91.36 \pm 0.13$ & $85.00 \pm 0.04$ \\
\hline 8 & 4.0 & 42 & 4.4 & $95.95 \pm 0.38$ & $89.45 \pm 0.39$ \\
\hline 9 & -0.0 & 30 & 3.5 & $80.45 \pm 0.03$ & $82.20 \pm 0.91$ \\
\hline 10 & 5.0 & 30 & 3.5 & $85.62 \pm 0.01$ & $81.69 \pm 0.14$ \\
\hline 11 & 2.5 & 10 & 3.5 & $69.80 \pm 0.04$ & $55.25 \pm 0.68$ \\
\hline 12 & 2.5 & 50 & 3.5 & $91.60 \pm 0.29$ & $90.45 \pm 0.07$ \\
\hline 13 & 2.5 & 30 & 2.0 & $65.25 \pm 0.22$ & $69.30 \pm 0.26$ \\
\hline 14 & 2.5 & 30 & 5.0 & $89.85 \pm 0.20$ & $81.20 \pm 0.42$ \\
\hline 15 & 2.5 & 30 & 3.5 & $71.50 \pm 0.44$ & $63.10 \pm 0.13$ \\
\hline 16 & 2.5 & 30 & 3.5 & $72.05 \pm 0.15$ & $62.50 \pm 0.14$ \\
\hline 17 & 2.5 & 30 & 3.5 & $71.95 \pm 0.43$ & $63.01 \pm 0.026$ \\
\hline 18 & 2.5 & 30 & 3.5 & $72.42 \pm 0.02$ & $62.90 \pm 0.35$ \\
\hline 19 & 2.5 & 30 & 3.5 & $71.15 \pm 0.38$ & $63.05 \pm 0.39$ \\
\hline
\end{tabular}

TABLE 3: Matrix of the central composite design for three variables and the measured responses (LAB viability, yeast viability, $\mathrm{pH}$, and overall acceptability).

\begin{tabular}{|c|c|c|c|c|c|c|c|}
\hline \multirow[b]{2}{*}{ Run } & \multicolumn{3}{|c|}{ Independent variables } & \multicolumn{2}{|c|}{ Response variables } & \multirow[b]{2}{*}{$\mathrm{pH}$} & \multirow[b]{2}{*}{$\begin{array}{c}\text { Overall } \\
\text { acceptability }\end{array}$} \\
\hline & $\begin{array}{c}X_{1} \text { (whey permeate, } \\
\% \mathrm{w} / \mathrm{v})\end{array}$ & $\begin{array}{c}X_{2} \text { (myrte juice, } \\
\% \mathrm{w} / \mathrm{v})\end{array}$ & $\begin{array}{c}X_{3} \text { (kefir grains, } \\
\% \mathrm{w} / \mathrm{v})\end{array}$ & $\begin{array}{c}\text { LAB viability } \\
\left(\log _{10} \mathrm{CFU} / \mathrm{mL}\right)\end{array}$ & $\begin{array}{c}\text { Yeast viability } \\
\left(\log _{10} \mathrm{CFU} / \mathrm{mL}\right)\end{array}$ & & \\
\hline 1 & 1.0 & 18 & 2.6 & $6.28 \pm 0.06$ & $4.15 \pm 0.01$ & $5.02 \pm 0.01$ & $3.90 \pm 0.10$ \\
\hline 2 & 4.0 & 18 & 2.6 & $6.80 \pm 0.06$ & $4.61 \pm 0.06$ & $4.88 \pm 0.02$ & $4.90 \pm 0.20$ \\
\hline 3 & 1.0 & 42 & 2.6 & $6.02 \pm 0.03$ & $4.85 \pm 0.02$ & $4.78 \pm 0.06$ & $4.90 \pm 0.10$ \\
\hline 4 & 4.0 & 42 & 2.6 & $7.39 \pm 0.04$ & $5.68 \pm 0.09$ & $4.69 \pm 0.04$ & $4.40 \pm 0.10$ \\
\hline 5 & 1.0 & 18 & 4.4 & $6.98 \pm 0.04$ & $5.50 \pm 0.07$ & $4.45 \pm 0.05$ & $4.10 \pm 0.20$ \\
\hline 6 & 4.0 & 18 & 4.4 & $7.09 \pm 0.02$ & $5.17 \pm 0.04$ & $4.41 \pm 0.04$ & $4.60 \pm 0.10$ \\
\hline 7 & 1.0 & 42 & 4.4 & $7.10 \pm 0.02$ & $5.11 \pm 0.03$ & $4.36 \pm 0.03$ & $5.60 \pm 0.10$ \\
\hline 8 & 4.0 & 42 & 4.4 & $9.23 \pm 0.03$ & $6.21 \pm 0.07$ & $4.21 \pm 0.03$ & $5.10 \pm 0.20$ \\
\hline 9 & -0.0 & 30 & 3.5 & $5.47 \pm 0.09$ & $4.79 \pm 0.01$ & $4.54 \pm 0.04$ & $4.90 \pm 0.10$ \\
\hline 10 & 5.0 & 30 & 3.5 & $8.25 \pm 0.04$ & $6.02 \pm 0.01$ & $4.39 \pm 0.03$ & $4.10 \pm 0.00$ \\
\hline 11 & 2.5 & 10 & 3.5 & $7.90 \pm 0.02$ & $5.19 \pm 0.03$ & $4.41 \pm 0.05$ & $4.70 \pm 0.10$ \\
\hline 12 & 2.5 & 50 & 3.5 & $8.30 \pm 0.03$ & $5.90 \pm 0.06$ & $4.19 \pm 0.04$ & $5.60 \pm 0.26$ \\
\hline 13 & 2.5 & 30 & 2.0 & $6.83 \pm 0.06$ & $4.39 \pm 0.03$ & $4.65 \pm 0.01$ & $4.60 \pm 0.10$ \\
\hline 14 & 2.5 & 30 & 5.0 & $8.67 \pm 0.04$ & $5.29 \pm 0.04$ & $3.94 \pm 0.05$ & $4.50 \pm 0.00$ \\
\hline 15 & 2.5 & 30 & 3.5 & $7.60 \pm 0.07$ & $5.10 \pm 0.02$ & $4.35 \pm 0.03$ & $4.40 \pm 0.36$ \\
\hline 16 & 2.5 & 30 & 3.5 & $7.60 \pm 0.03$ & $5.31 \pm 0.03$ & $4.31 \pm 0.02$ & $3.40 \pm 0.10$ \\
\hline 17 & 2.5 & 30 & 3.5 & $7.41 \pm 0.04$ & $5.25 \pm 0.03$ & $4.29 \pm 0.08$ & $4.10 \pm 0.10$ \\
\hline 18 & 2.5 & 30 & 3.5 & $7.70 \pm 0.03$ & $5.19 \pm 0.06$ & $4.30 \pm 0.02$ & $3.95 \pm 0.05$ \\
\hline 19 & 2.5 & 30 & 3.5 & $7.67 \pm 0.02$ & $5.26 \pm 0.04$ & $4.29 \pm 0.02$ & $4.05 \pm 0.35$ \\
\hline
\end{tabular}

Overall acceptability score (9-point hedonic scale).

the reasons, and their antioxidant capacity is always associated with their health-promoting properties. HernándezLedesma et al. [52] reported the antioxidant activity for some peptide chains in whey, which had higher radical scavenging activity than butylated hydroxyanisole (BHA). The antioxidant activity of kefir has also been shown, and it is due to some potential compounds like glutathione, organic acids, and kefiran $[8,51,53]$.

The multiple coded equations in terms of coded factors generated for these responses are shown as follows: 
TABLE 4: Analysis terms for the quadratic model representing the investigated responses (TPC, DPPH (\%), LAB and yeasts' number, pH, and overall acceptability).

\begin{tabular}{|c|c|c|c|c|c|c|}
\hline Model terms & Coefficient estimate & t.exp & $p$ value & Coefficient estimate & t.exp. & $p$ value \\
\hline Total phenolic content $(\mathrm{mg} / \mathrm{mL})$ & & & & DPPH scavenging activity (\%) & & \\
\hline$b_{0}$ & 63.199 & 584.42 & $* * *$ & 71.950 & 325.27 & $* * *$ \\
\hline$b_{1}$ & 0.386 & 5.89 & $* *$ & 1.804 & 13.46 & $* * *$ \\
\hline$b_{2}$ & 7.620 & 116.32 & $* * *$ & 6.255 & 46.68 & $* * *$ \\
\hline$b_{3}$ & 6.545 & 99.91 & $* * *$ & 6.241 & 46.57 & $* * *$ \\
\hline$b_{11}$ & 5.148 & 78.57 & $* * *$ & 3.220 & 24.02 & $* * *$ \\
\hline$b_{22}$ & 1.933 & 29.50 & $* * *$ & 2.394 & 17.86 & $* * *$ \\
\hline$b_{33}$ & 2.781 & 42.45 & $* * *$ & 1.280 & 9.55 & $* *$ \\
\hline$b_{12}$ & 0.046 & 0.54 & NS & 0.243 & 1.39 & NS \\
\hline$b_{13}$ & 0.524 & 6.12 & $* *$ & -0.145 & -0.83 & NS \\
\hline$b_{23}$ & 2.841 & 33.20 & $* * *$ & 4.632 & 26.46 & $* * *$ \\
\hline$R^{2}$ & 0.843 & & & 0.966 & & \\
\hline Adj. $R^{2}$ & 0.686 & & & 0.931 & & \\
\hline$L A B\left(\log _{10} C F U / m L\right)$ & & & & Yeasts $\left(\log _{10} C F U / m L\right)$ & & \\
\hline$b^{0}$ & 7.614 & 151.07 & $* * *$ & 5.226 & 145.45 & $* * *$ \\
\hline$b^{1}$ & 0.645 & 21.12 & $* * *$ & 0.302 & 13.88 & $* * *$ \\
\hline$b^{2}$ & 0.239 & 7.83 & $* *$ & 0.265 & 12.16 & $* * *$ \\
\hline$b^{3}$ & 0.513 & 16.80 & $* * *$ & 0.309 & 14.18 & $* * *$ \\
\hline$b^{11}$ & -0.358 & 11.71 & $* * *$ & 0.042 & 1.93 & NS \\
\hline$b^{22}$ & 0.081 & 2.64 & NS & 0.092 & 4.21 & $*$ \\
\hline$b^{33}$ & -0.043 & -1.41 & NS & -0.158 & -7.24 & $* *$ \\
\hline$b^{12}$ & 0.359 & 8.99 & $* *$ & 0.225 & 7.91 & $* *$ \\
\hline$b^{13}$ & 0.044 & 1.10 & NS & -0.065 & -2.29 & NS \\
\hline$b^{23}$ & 0.241 & 6.05 & $* *$ & -0.140 & -4.92 & $* *$ \\
\hline$R^{2}$ & 0.909 & & & 0.942 & & \\
\hline $\operatorname{Adj} . R^{2}$ & 0.818 & & & 0.885 & & \\
\hline$p H$ & & & & Overall acceptability & & \\
\hline$b_{0}$ & 4.299 & 386.48 & $* * *$ & 3.984 & 26.50 & $* * *$ \\
\hline$b_{1}$ & -0.049 & -7.31 & $* *$ & -0.062 & -0.68 & NS \\
\hline$b_{2}$ & -0.080 & -11.85 & $* * *$ & 0.294 & 3.23 & $*$ \\
\hline$b_{3}$ & -0.229 & -34.06 & $* * *$ & 0.083 & 0.91 & NS \\
\hline$b_{11}$ & 0.108 & 15.95 & $* * *$ & 0.164 & 1.80 & NS \\
\hline$b_{22}$ & 0.049 & 7.30 & $* *$ & 0.394 & 4.33 & $* *$ \\
\hline$b_{33}$ & 0.047 & 7.04 & $* *$ & 0.182 & 2.00 & NS \\
\hline$b_{12}$ & -0.008 & -0.85 & NS & -0.312 & -2.63 & $*$ \\
\hline$b_{13}$ & 0.005 & 0.57 & NS & -0.062 & -0.53 & NS \\
\hline$b_{23}$ & 0.017 & 1.99 & NS & 0.187 & 1.58 & NS \\
\hline$R^{2}$ & 0.836 & & & 0.827 & & \\
\hline $\operatorname{Adj} . R^{2}$ & 0.672 & & & 0.654 & & \\
\hline
\end{tabular}

NS: nonsignificant; ${ }^{*} p<0.05,{ }^{* *} p<0.01$, and ${ }^{* * *} p<0.001$.

$$
\begin{aligned}
\mathrm{TPC} & =63.199+0.386 X_{1}+7.620 X_{2}+6.545 X_{3}+5.148 X_{1}^{2}+1.933 X_{2}^{2}+2.781 X_{3}^{2}+0.524 X_{13}+2.841 X_{23}, \\
\mathrm{DPPH} \% & =71.95+1.804 X_{1}+6.255 X_{2}+6.241 X_{3}+3.22 X_{1}^{2}+2.394 X_{2}^{2}+1.28 X_{3}^{2}+4.632 X_{2} X_{3} .
\end{aligned}
$$

3.2. Effects of the Variables on $p H$ and LAB and Yeast Cell Viability of Kefir Microorganisms. The effects of independent variables on LAB and yeast cell viability are shown in Table 3. Their number depends on whey permeate, fruit juice, and kefir inoculum level. The linear effects were significantly positive $(p<0.001$; Table 4$)$. The interaction effects of whey permeate-fruit juice and fruit-kefir grains were also significant $(p<0.01$; Table 4$)$. An increasing inoculum level allows enhancing LAB and yeasts' number. The same result was observed by Sabokbar and Khodaiyn [9] when they fermented a mixture of pomegranate juice and whey by kefir grains. They reported that the cell density of LAB increased by 1.3 Ulog when they increase the inoculum from $5 \%$ to $8 \%$. However, for yeasts' number, nonsignificant difference was observed. M'hir et al. [11] obtained the same result when they prepared a fermented beverage from whey, whey permeate, and date syrup and when they prepared a kefir beverage made with carob, oat flour, and whey permeate [54]. This increase of LAB due to the increase of the level of juice can be explained by the probiotic effect of myrtle (Figure 4). In fact, in the studies of Mangia et al. [55] and Öztürk et al. [56], they showed that myrtle juice exerts a positive effect on lactobacilli. 

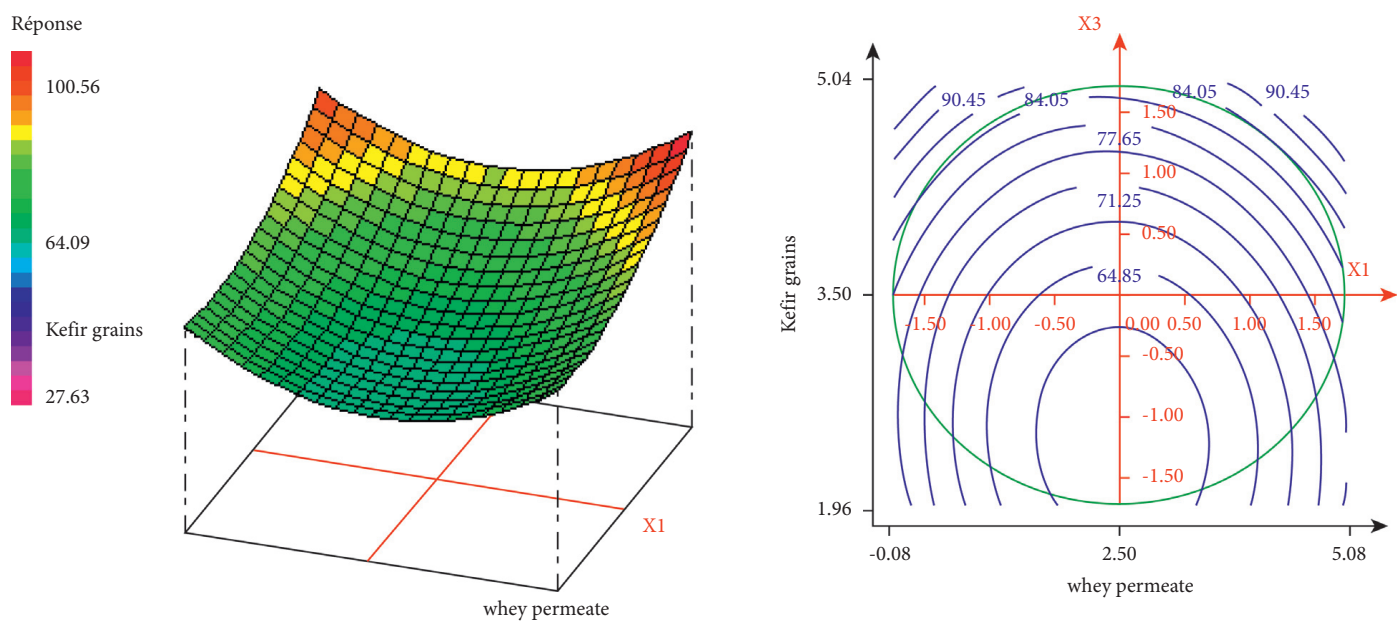

(a)
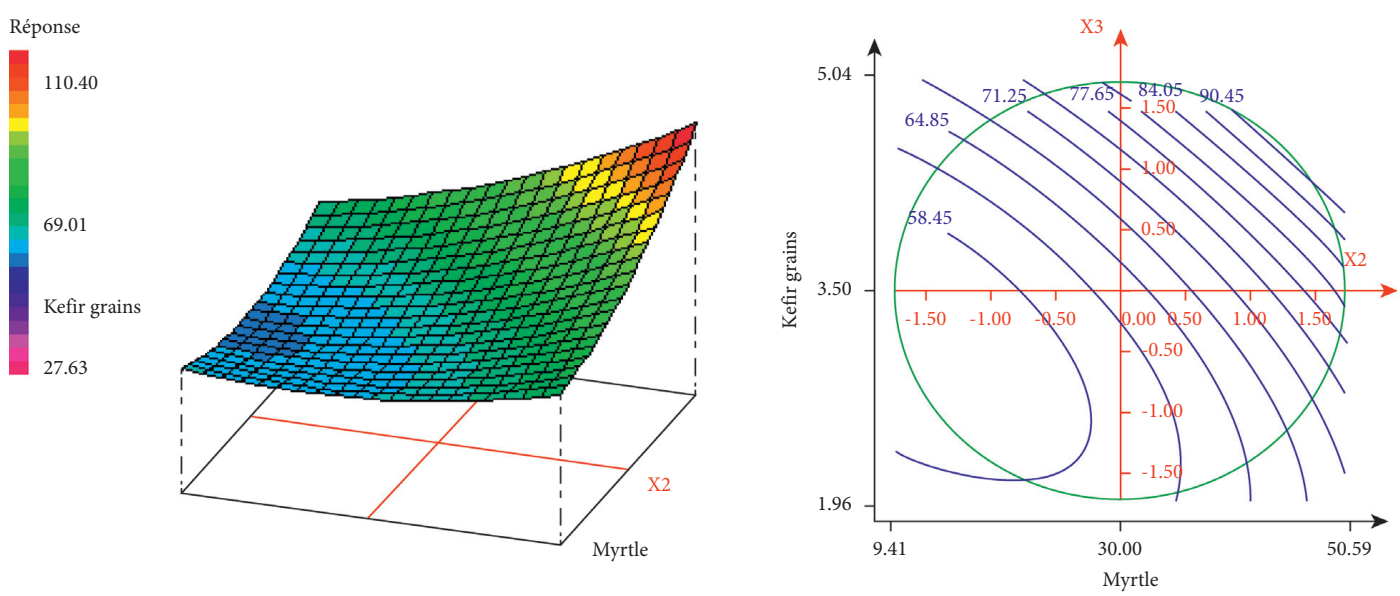

(b)

FIGURE 2: Response surface and contour plots representing the effect of WP and KG (a) and the effect of MJ and KG (b) on total polyphenol content $\left(X_{1}:\right.$ WP $(\% \mathrm{w} / \mathrm{v}) ; X_{2}: \mathrm{MJ}(\% \mathrm{w} / \mathrm{v})$; and $\left.X_{3}: \mathrm{KG}(\% \mathrm{w} / \mathrm{v})\right)$.
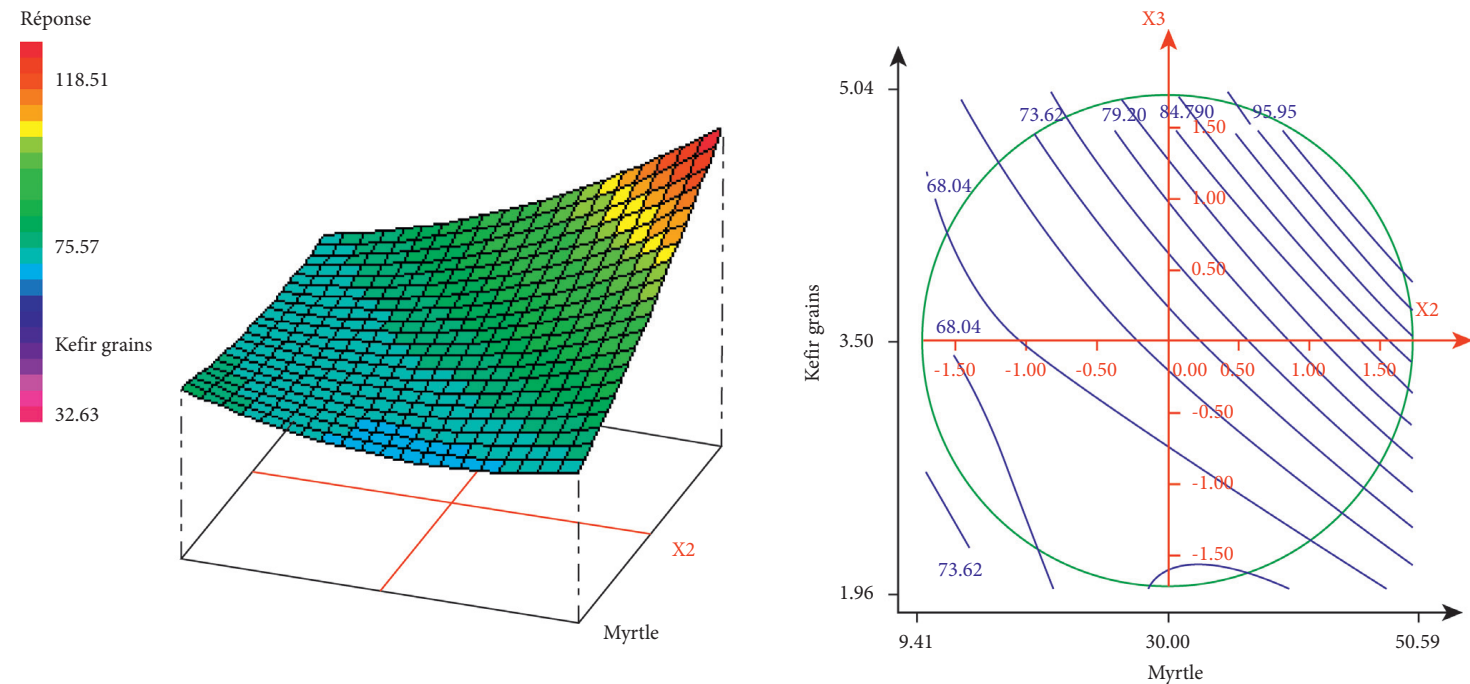

FIGURE 3: Response surface and contour plots representing the effect of MJ and KG on DPPH radical scavenging activity (\%; $X_{2}:$ MJ (\% w/v) and $X_{3}:$ KG $\left.(\% \mathrm{w} / \mathrm{v})\right)$. 
TABLE 5: Levels of total phenolic content and antioxidant activities before and after fermentation for each beverage.

\begin{tabular}{|c|c|c|c|c|}
\hline \multirow{2}{*}{$\operatorname{Exp}$} & \multicolumn{2}{|c|}{ Total phenolic content (mg GAE/mL) } & \multicolumn{2}{|c|}{ Antioxidant activities (\%) } \\
\hline & Unfermented & Fermented & Unfermented & Fermented \\
\hline 1 & $48.75^{\mathrm{b}} \pm 0.70$ & $57.58^{\mathrm{b}} \pm 0.69$ & $60.88^{\mathrm{a}} \pm 0.51$ & $68.40^{\mathrm{b}} \pm 0.67$ \\
\hline 2 & $49.88^{\mathrm{b}} \pm 0.17$ & $59.75^{\mathrm{c}} \pm 0.56$ & $63.15^{b} \pm 0.91$ & $72.60^{\mathrm{fg}} \pm 0.31$ \\
\hline 3 & $58.46^{\mathrm{de}} \pm 0.70$ & $64.80^{\mathrm{e}} \pm 0.56$ & $63.88^{\mathrm{b}} \pm 0.45$ & $71.25^{\mathrm{de}} \pm 0.75$ \\
\hline 4 & $57.20^{\mathrm{d}} \pm 0.96$ & $63.60^{\mathrm{de}} \pm 0.47$ & $65.77^{\mathrm{c}} \pm 0.74$ & $75.60^{\mathrm{h}} \pm 0.43$ \\
\hline 5 & $52.75^{\mathrm{c}} \pm 0.63$ & $69.97^{\mathrm{fg}} \pm 0.49$ & $60.76^{\mathrm{a}} \pm 0.62$ & $70.80^{\mathrm{cd}} \pm 0.28$ \\
\hline 6 & $59.00^{\mathrm{ef}} \pm 0.44$ & $70.68^{g} \pm 0.39$ & $65.20^{c} \pm 0.42$ & $73.60^{\mathrm{g}} \pm 0.38$ \\
\hline 7 & $57.25^{\mathrm{d}} \pm 0.89$ & $85.00^{\mathrm{i}} \pm 0.14$ & $69.45^{\mathrm{e}} \pm 0.77$ & $91.36^{1} \pm 0.70$ \\
\hline 8 & $58.91^{\mathrm{ef}} \pm 0.96$ & $89.45^{\mathrm{j}} \pm 0.62$ & $71.49^{\mathrm{f}} \pm 0.41$ & $95.95^{\mathrm{m}} \pm 0.76$ \\
\hline 9 & $60^{\mathrm{fg}} \pm 0.45$ & $82.20^{\mathrm{h}} \pm 0.26$ & $67.77^{\mathrm{d}} \pm 0.35$ & $80.45^{\mathrm{i}} \pm 0.65$ \\
\hline 10 & $63.89^{\mathrm{h}} \pm 0.28$ & $81.69^{\mathrm{h}} \pm 0.70$ & $71.67^{\mathrm{f}} \pm 0.88$ & $85.62^{\mathrm{j}} \pm 0.65$ \\
\hline 11 & $45.11^{\mathrm{a}} \pm 0.19$ & $55.25^{\mathrm{a}} \pm 0.34$ & $60.78^{a} \pm 0.75$ & $69.80^{c} \pm 0.24$ \\
\hline 12 & $60.68^{g} \pm 0.51$ & $90.45^{j} \pm 0.79$ & $75.94^{\mathrm{g}} \pm 0.53$ & $91.60^{1} \pm 0.51$ \\
\hline 13 & $58.30^{\mathrm{de}} \pm 0.91$ & $69.30^{\mathrm{f}} \pm 0.77$ & $60.76^{\mathrm{a}} \pm 0.36$ & $65.25^{\mathrm{a}} \pm 0.32$ \\
\hline 14 & $58.91^{\mathrm{ef}} \pm 0.96$ & $81.20^{\mathrm{h}} \pm 0.26$ & $68.25^{\mathrm{de}} \pm 0.91$ & $89.85^{\mathrm{k}} \pm 0.51$ \\
\hline 15 & $52.10^{c} \pm 0.28$ & $63.10^{\mathrm{d}} \pm 0.67$ & $65.61^{c} \pm 0.57$ & $71.50^{\text {def }} \pm 0.33$ \\
\hline 16 & $52.73^{c} \pm 0.40$ & $62.50^{\mathrm{d}} \pm 0.14$ & $65.61^{c} \pm 0.12$ & $72.05^{\mathrm{ef}} \pm 0.84$ \\
\hline 17 & $51.77^{\mathrm{c}} \pm 0.33$ & $63.01^{\mathrm{d}} \pm 0.09$ & $65.96^{\mathrm{c}} \pm 0.15$ & $71.95^{\mathrm{def}} \pm 0.84$ \\
\hline 18 & $52.77^{\mathrm{c}} \pm 0.45$ & $62.90^{\mathrm{d}} \pm 0.84$ & $65.23^{\mathrm{c}} \pm 0.30$ & $72.42^{\mathrm{ef}} \pm 0.79$ \\
\hline 19 & $52.05^{\mathrm{c}} \pm 0.44$ & $63.05^{\mathrm{d}} \pm 0.93$ & $66.12^{c} \pm 0.12$ & $71.15^{\mathrm{de}} \pm 0.30$ \\
\hline
\end{tabular}

Values are expressed as mean \pm standard deviation (three determinations). Data in the same row with different superscript letters are significantly different at $p<0.05$.
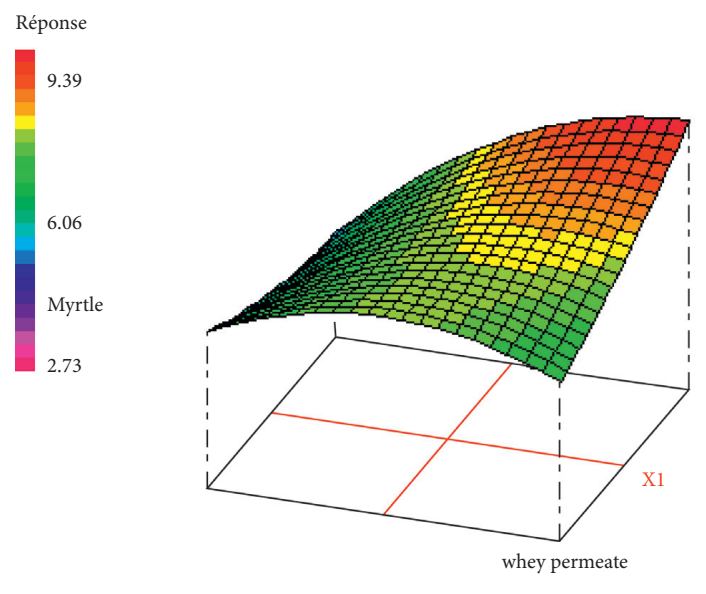

(a)
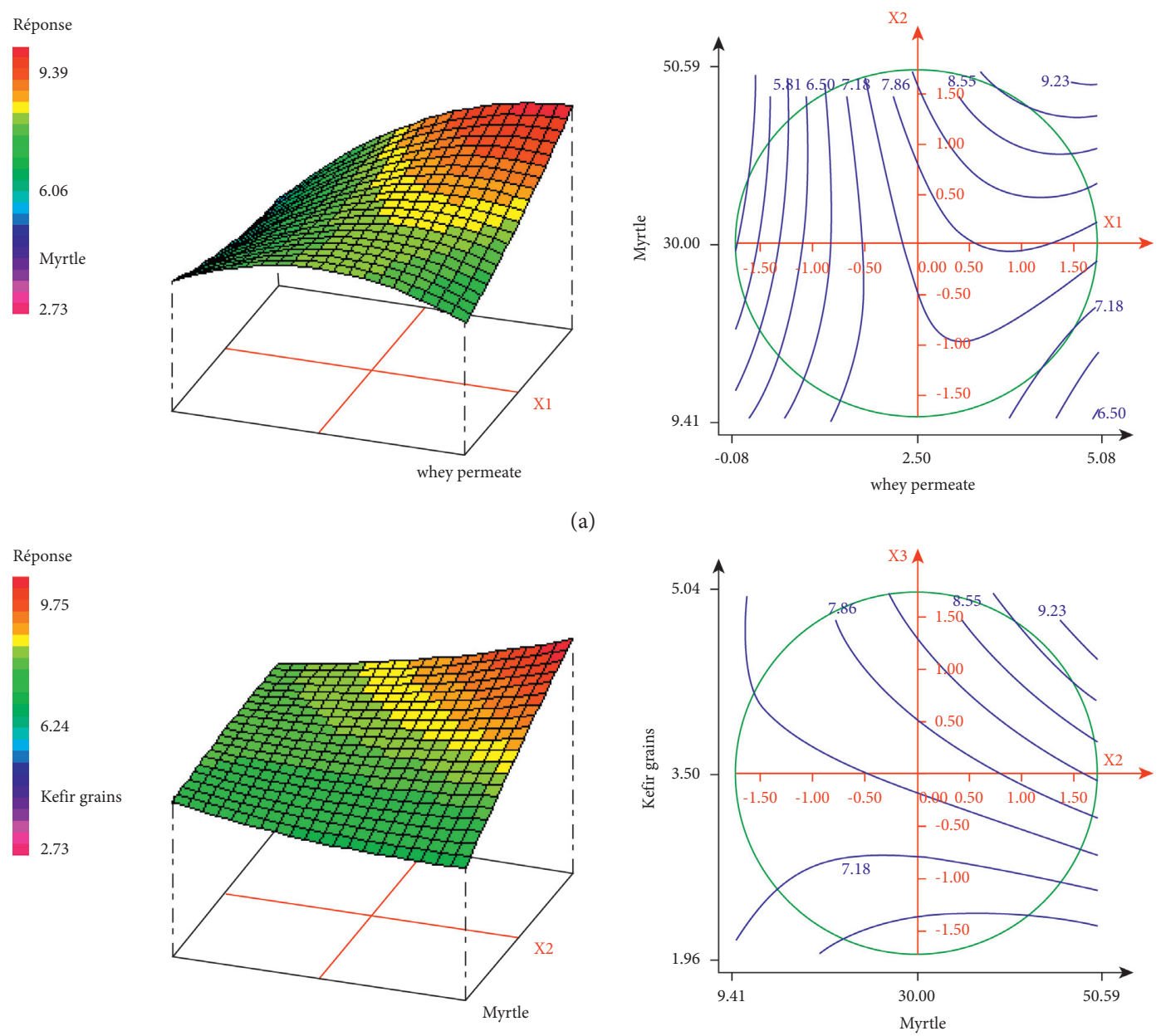

(b)

FIGURE 4: Response surface and contour plots representing the effect of WP and MJ (a) and the effect of MJ and KG (b) on LAB count $\left(X_{1}\right.$ : WP $(\% \mathrm{w} / \mathrm{v}) ; X_{2}:$ MJ $\left.(\% \mathrm{w} / \mathrm{v}) ; X_{3}: \mathrm{KG}(\% \mathrm{w} / \mathrm{v})\right)$. 
The positive interaction between myrtle juice and kefir inoculum on cell density was significant ( $p<0.01$; Table 4$)$. Filannino et al. [45] showed that phenolic compounds can exert a positive effect on LAB growth.

As a consequence of kefir microflora growth, the $\mathrm{pH}$ decline during fermentation ( $\mathrm{pH}$ ranging between 5.02 and 3.94; Table 3) due to lactic acid increase, which can inhibit spoilage and pathogenic bacteria development in the beverage [9]. The $\mathrm{pH}$ decrease was significantly related to whey permeate $(p<0.01)$, juice $(p<0.001)$, kefir grains $(p<0.001)$, and their quadratic effects $(p<0.01)$. However, the $\mathrm{pH}$ was not significantly influenced by their interaction (Table 4).

The number of viable cells of yeast and LAB of the obtained beverage were in accordance with codex Standard FAO/WHO [57], suggesting at least $10^{4}$ and $10^{7} \mathrm{CFU} / \mathrm{mL}$ of bacteria and yeast counts, respectively.

The multiple coded equations in terms of coded factors generated for these responses are shown as follows:

$$
\begin{aligned}
\mathrm{LAB} & =7.614+0.645 X_{1}+0.239 X_{2}+0.513 X_{3}-0.358 X_{1}^{2}+0.359 X_{12}+0.241 X_{23}, \\
\text { Yeasts } & =5.226+0.302 X_{1}+0.265 X_{2}+0.309 X_{3}+0.092 X_{2}^{2}-0.158 X_{3}^{2}+0.225 X_{12}-0.14 X_{23}, \\
\mathrm{pH} & =4.229-0.049 X_{1}-0.08 X_{2}-0.229 X_{3}+0.108 X_{1}^{2}+0.049 X_{2}^{2}+0.047 X_{3}^{2} .
\end{aligned}
$$

3.3. Effects of the Variables on Sensory Evaluation. Sensory analysis is a real lever for the development of new food products. Indeed, the characterization of their organoleptic properties is essential to guarantee their acceptability by consumers.

Only myrtle juice linear and quadratic terms $\left(b_{2}\right.$ and $\left.b_{22}\right)$ have relevant effects on the overall acceptability (Table 4). As noticed in Figure 5, a significant interaction was detected between whey permeate $\left(X_{1}\right)$ and myrtle juice $\left(X_{2}\right)$. The OA scores ranged from $3.9 \pm 0.1$ to $5.6 \pm 0.26$ on a 9-point hedonic scale (Table 3 ). The most appreciated samples were the beverages from experiment 7 (1\% WP, $42 \%$ myrtle juice, and $4.4 \%$ kefir grains) and 12 (2.5\% WP, 50\% myrtle juice, and $3.5 \%$ kefir grains). The acceptability ratings were highest in the samples containing a high amount of fruit juice. It can be explained by the fact that Myrtle's juice masked the unsavory taste of cheese whey. In the study of Öztürk et al. [56], black and white myrtles improved the taste scores of probiotic goat milk ice cream samples by masking the low $\mathrm{pH}$ resulting from fermentation. Koksoy and Kilic [58] showed that acid odor was masked with the fruit aromas resulting in more acceptable drinks for consumption.

The level of juice and whey used in many studies was different; it largely depends on the fruit matrix. For example, Islam et al. [12] suggested that the optimum formula was with $25 \%$ whey and $75 \%$ pineapple juice. However, Pereira et al. [59] added only $10 \%$ of mango fruit to liquid whey protein and concentrated permeates.

Phenolic compounds contained in myrtle juice have also an impact on the obtained beverages' sensory attributes. Indeed, they have an important effect on color, perceived taste, and flavor. Pinto and Vilela [60] reported that different color palettes may influence our taste and flavor perception. The polynomial model for $\mathrm{OA}$ is presented by the following equation:

$$
\mathrm{OA}=3.984+0.294 X_{2}+0.394 X_{2}^{2}-0.312 X_{1} X_{2} .
$$

3.4. Validation. Validation tests were performed in order to determine the LAB and yeasts' cell count, the $\mathrm{pH}$, the TPC, the DPPH antioxidant activity, and OA under optimized condition $(2.83 \%(\mathrm{w} / \mathrm{v})$ at whey permeate, $48.45 \%(\mathrm{w} / \mathrm{v})$ myrtle juice, and $3.71 \%(\mathrm{w} / \mathrm{v})$ inoculum). The validation results are demonstrated in Table 6 in which the number of $\mathrm{LAB}$ and yeasts, the antioxidant activity, TPC, and the OA were mentioned. TPC showed a lower value than the predicted ones. Taking into account the standard deviations of measured and calculated responses, the results obtained indicated that the experimental values were in good agreement with the predicted values. This suggested that the fitted model is satisfactory and accurate.

3.5. Microbial Viability of Kefir Culture and the Change in Physicochemical Parameters during Storage. The results for the effects of storage temperature at $4^{\circ} \mathrm{C}$ on the counting of $\mathrm{LAB}$ and yeasts and on physicochemical parameters of the developed beverage are shown in Table 7 . A reduction in the load of LAB was observed from the first day of storage. LAB were more sensitive to storage than yeasts. Indeed, the loss in the viability of LAB cells was more important than this of yeasts. A very little and nonsignificant decrease of yeasts counts was recorded after 14 days of storage at $4^{\circ} \mathrm{C}$. However, the viability is maintained during the two weeks of storage at a high level for all tested microflora as recommended by FAO/WHO 2006 [57]. The number of LAB and yeast viable cells was $7.61 \pm 0.14$ and $6.19 \pm 0.24$, respectively, after 2 weeks of storage at $4^{\circ} \mathrm{C}$. These results were in agreement with the reports of previous investigators [59, 61]. The microorganisms' viability largely depended both on medium composition and on storage temperature. The $\mathrm{pH}$ influence on cell viability has been widely mentioned [62]. Existing exopolysaccharides, as kefiran, might help improve the survival of microorganisms in an acidic or frozen medium by giving a protective envelop that may preserve them from stressful conditions. The resistance of LAB in acidic conditions is due to the action of the proton pump, the change in their cell membrane composition, and other mechanisms [63]. Nualkaekul and Charalampopoulos [64] suggested that Lactobacillus probably uses the energy 

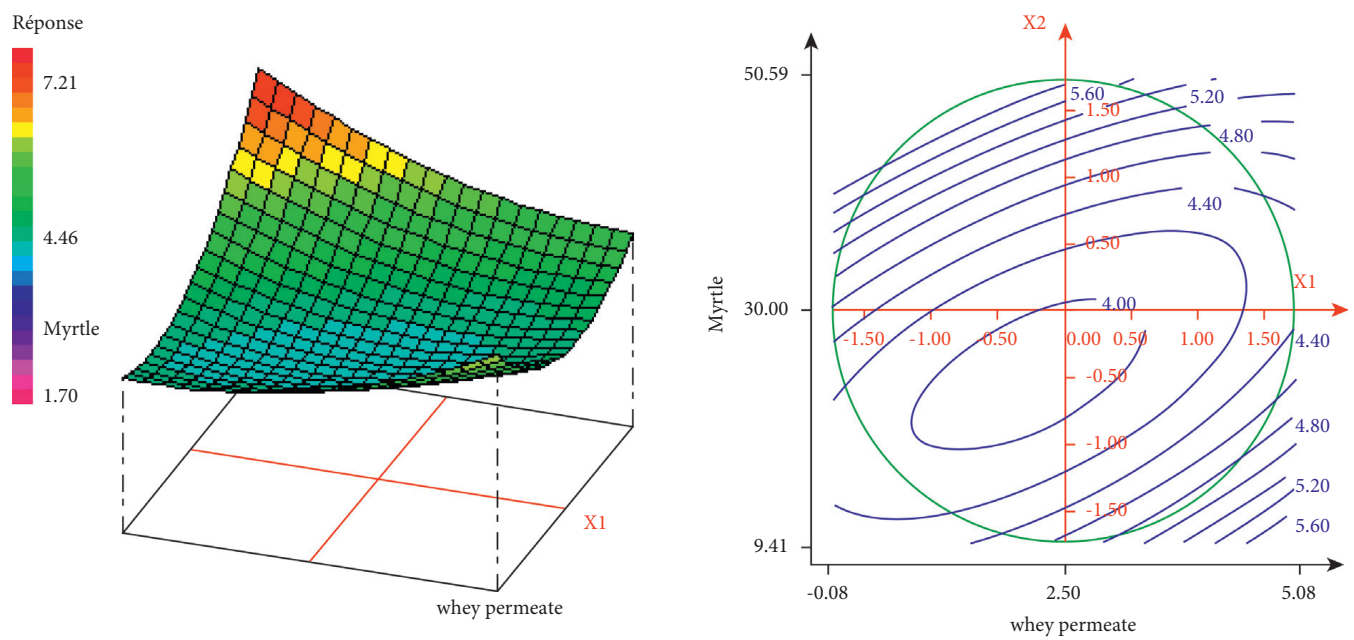

Figure 5: Response surface and contour plots representing the effect of WP and MJ on overall acceptability $\left(X_{1}: \mathrm{WP}(\% \mathrm{w} / \mathrm{v})\right.$ and $X_{2}: \mathrm{MJ}(\%$ $\mathrm{w} / \mathrm{v}))$.

TABLE 6: Predicted and experimental values of responses under optimum conditions.

\begin{tabular}{lcc}
\hline Response variables & Experimental & Predicted \\
\hline TPC $(\mathrm{mg}$ GAE$/ \mathrm{mL})$ & $81.56 \pm 0.78$ & 82.77 \\
DPPH $(\%)$ & $91.61 \pm 0.61$ & 91.26 \\
LAB viability $\left(\log _{10} \mathrm{CFU} / \mathrm{mL}\right)$ & $8.53 \pm 0.30$ & 8.64 \\
Yeast viability $\left(\log _{10} \mathrm{CFU} / \mathrm{mL}\right)$ & $6.21 \pm 0.27$ & 6.01 \\
pH & $4.18 \pm 0.02$ & 4.24 \\
OA score & $5.41 \pm 0.25$ & 5.37 \\
\hline
\end{tabular}

Mean values \pm standard deviation (duplicate determination); OA score on $1-9$ scale (with $100 \% d(i)$ : the percentage of calculated desirability).

TABLE 7: Microbial viability and the change in physicochemical parameters during refrigerated storage.

\begin{tabular}{|c|c|c|c|c|c|c|}
\hline & $\begin{array}{c}\text { LAB }\left(\log _{10} \mathrm{CFU} /\right. \\
\mathrm{mL})\end{array}$ & $\begin{array}{l}\text { Yeast }\left(\log _{10} \mathrm{CFU} /\right. \\
\mathrm{mL})\end{array}$ & $\begin{array}{l}\text { Total polyphenol content } \\
(\mathrm{mg} \text { EAG } / \mathrm{mL})\end{array}$ & $\begin{array}{c}\text { Scavenging activity (\%, } \\
\text { DPPH) }\end{array}$ & $\begin{array}{l}\text { Overall acceptability } \\
\quad(1-9 \text { scale })\end{array}$ & $\mathrm{pH}$ \\
\hline $0 \mathrm{j}$ & $8.53^{\mathrm{a}} \pm 0.60$ & $6.21^{\mathrm{a}} \pm 0.04$ & $81.56^{\mathrm{d}} \pm 0.50$ & $91.61^{\mathrm{d}} \pm 0.63$ & $5.41^{\mathrm{ab}} \pm 0.12$ & $4.18^{\mathrm{d}} \pm 0.02$ \\
\hline $1 \mathrm{j}$ & $7.85^{\mathrm{a}} \pm 0.18$ & $6.55^{\mathrm{a}} \pm 0.09$ & $76.13^{c} \pm 0.67$ & $88.44^{\mathrm{c}} \pm 0.71$ & $5.53^{b} \pm 0.17$ & $3.99^{c} \pm 0.02$ \\
\hline $7 \mathrm{j}$ & $7.89^{a} \pm 0.14$ & $6.23^{\mathrm{a}} \pm 0.16$ & $73.86^{b} \pm 0.67$ & $86.73^{\mathrm{b}} \pm 0.42$ & $5.44^{\mathrm{ab}} \pm 0.07$ & $3.82^{\mathrm{b}} \pm 0.02$ \\
\hline $14 \mathrm{j}$ & $7.61^{\mathrm{a}} \pm 0.14$ & $6.19^{\mathrm{a}} \pm 0.24$ & $69.12^{\mathrm{a}} \pm 0.15$ & $84.57^{\mathrm{a}} \pm 0.21$ & $5.13^{\mathrm{a}} \pm 0.06$ & $3.69^{\mathrm{a}} \pm 0.01$ \\
\hline
\end{tabular}

Mean \pm SD. Data in the same row with different superscript letters are significantly different at $p<0.05$.

generated through their metabolic activity in order to maintain their viability. During the storage time, the $\mathrm{pH}$ value decreased to 3.69 with the progress of the storage period. This acidification through storage could be caused by residual microbial activity. The same result was observed by Islam et al. [12].

The storage has a significant impact on polyphenol content and antioxidant activity. A significant decrease of TPC and of DPPH free radical scavenging activity (\%) was observed during storage. The loss of phenolic compounds could be explained by their oxidation.

On day 1 of the postproduction, the sensory properties of the fermented beverage have been slightly improved and then decreased under refrigerated storage. The decrease in product quality was linked to the increase in the contents of organic acids. Indeed, a mild increase in acidity was observed from the second day of storage.

\section{Conclusions}

The supplementation of cheese whey allowed developing kefir-like beverage having functional proprieties such as high polyphenol content and good antioxidant capacity. The RSM was successfully employed to optimize the LAB and yeast cell counts, the TPC, the antioxidant activity, and the $\mathrm{OA}$ with the incorporation of different concentrations of WP, myrtle juice, and kefir grains. The beverage obtained by mixing $(2.83 \%$ whey permeate and $3.71 \%$ kefir grains) gave acceptable sensorial properties. The enumeration of LAB and yeast cells showed that the obtained beverage fulfilled the criterion of probiotic beverage in an acceptable manner even after 14 days of storage at $4^{\circ} \mathrm{C}$. Sensory attributes may be ameliorated with further investigations like using myrtle syrup and/or adding another carbon source. 


\section{Data Availability}

The data used to support the findings of this study are included within the article (Tables 2-7).

\section{Conflicts of Interest}

The authors declare that there are no conflicts of interest regarding the publication of this paper.

\section{Acknowledgments}

The financial support of the Tunisian Ministry of Higher Education and Scientific Research is gratefully acknowledged.

\section{Supplementary Materials}

Analyses of variance of central composite design are provided in Supplementary Materials. (Supplementary Materials)

\section{References}

[1] APII, Les Industries Agroalimentaires en Tunisie: Industrie des Boissons, Agency for the Promotion of Industry and Innovation, Tunisia, 2014.

[2] M. Kasmi, "Biological processes as promoting way for both treatment and valorization of dairy industry effluents," Waste and Biomass Valorization, vol. 9, no. 2, pp. 195-209, 2016.

[3] F. Carvalho, A. R. Prazeres, and J. Rivas, "Cheese whey wastewater: characterization and treatment," The Science of the Total Environment, vol. 445-446, pp. 385-396, 2013.

[4] A. Panghal, R. Patidar, S. Jaglan et al., "Whey valorization: current options and future scenario - a critical review," Nutrition \& Food Science, vol. 48, no. 3, pp. 520-535, 2018.

[5] O. Kareb and M. Aïder, "Whey and its derivatives for probiotics, prebiotics, synbiotics, and functional foods: a critical review," Probiotics and Antimicrobial Proteins, vol. 11, no. 2, pp. 348-369, 2018.

[6] P. Pásmándi, Z. Kovács, and A. Máráz, "Potential of Lactobacillus strains for the production of fermented functional beverages enriched in galacto-oligosaccharides," LWT, vol. 143, Article ID 111097, 2021.

[7] R. McCarthy, S. Mills, R. P. Ross, G. F. Fitzgerald, and C. Stanton, "Bioactive peptides from casein and whey proteins," Milk and Dairy Products as Functional Foods, vol. 2, pp. 23-54, 2014.

[8] N. F. Azizi, M. R. Kumar, S. K. Yeap et al., "Kefir and its biological activities," Foods, vol. 10, no. 6, p. 1210, 2021.

[9] N. Sabokbar and F. Khodaiyan, "Characterization of pomegranate juice and whey based novel beverage fermented by kefir grains," Journal of Food Science \& Technology, vol. 52, no. 6, pp. 3711-3718, 2015.

[10] N. Sabokbar, M. Moosavi-Nasab, and F. Khodaiyan, "Preparation and characterization of an apple juice and whey based novel beverage fermented using kefir grains," Food Science and Biotechnology, vol. 24, no. 6, pp. 20195-22104, 2015.

[11] S. M'hir, K. Rtibi, A. Mejri et al., "Development of a novel whey date beverage fermented with kefir grains using response surface methodology," Journal of Chemistry, vol. 2019, Article ID 1218058, 13 pages, 2019.
[12] M. Z. Islam, S. Tabassum, M. Harun-ur-Rashid, G. E. Vegarud, M. S. Alam, and M. A. Islam, "Development of probiotic beverage using whey and pineapple (Ananas comosus) juice: sensory and physico-chemical properties and probiotic survivability during in-vitro gastrointestinal digestion," Journal of Agriculture and Food Research, vol. 4, Article ID 100144, 2021.

[13] A. Panghal, S. Janghu, K. Virkar, Y. Gat, V. Kumar, and N. Chhikara, "Potential non-dairy probiotic products - a healthy approach," Food Bioscience, vol. 21, pp. 80-89, 2018.

[14] A. Septembre-Malaterre, F. Remize, and P. Poucheret, "Fruits and vegetables, as a source of nutritional compounds and phytochemicals: changes in bioactive compounds during lactic fermentation," Food Research International, vol. 104, pp. 86-99, 2018.

[15] F. Giampieri, D. Ciancioso, and T. Y. Forbes-Hernandez, "Myrtle (Myrtus communis L.) berries, seeds, leaves, and essential oils: new undiscovered sources of natural compounds with promising health benefits," Food Frontiers, vol. 1, no. 3, pp. 276-295, 2020.

[16] S. Sumbul, A. Ahmad, M. Asif, and M. Akhtar, "Myrtus communis Linn.-a review," Indian Journal of Natural Products and Resources, vol. 2, pp. 395-402, 2011.

[17] C. S. Devaki and K. S. Premavalli, "Development of fermented beverage using RSM and nutrients evaluation-I. Fermented ashgourd beverage," Journal of Food Research, vol. 1, no. 3, 2012.

[18] D. B. Hibbert, "Vocabulary of concepts and terms in chemometrics (IUPAC Recommendations 2016)," Pure and Applied Chemistry, vol. 88, no. 4, pp. 407-443, 2016.

[19] W. Y. Koh, U. Utra, A. Rosma, M. E. Effariza, W. I. Wan Rosli, and Y.-H. Park, "Development of a novel fermented pumpkin- based beverage inoculated with water kefir grains: a response surface methodology approach," Food Science Biotechnology, vol. 27, pp. 525-535, 2018.

[20] S. M'hir, K. Rtibi, L. Ayed, M. Hamdi, L. Marzouki, and H. Sebai, "Evaluation de l'effect protecteur du lait de chèvre fermenté par le kefir et enrichi à la caroube contre l'ulcère gastrique induit par l'éthanol chez le rat," International Journal of Advanced Research, vol. 7, no. 4, pp. 1019-1028, 2019.

[21] S. M'hir, L. Ayed, and M. Hamdi, "Microbial flora associated with Tunisian household kefir," in Proceedings of the VIIème congrès International de Biotechnologie et Valorisation des BioRessources, Tabarka, Tunisia, March 2019.

[22] I. J. Jeon, S. J. Galitzer, and K. J. Hennessy, "Rapid determination of lactose and its hydrolyzates in whey and whey permeate by high performance liquid chromatography," Journal of Dairy Science, vol. 67, no. 4, pp. 884-887, 1984.

[23] International Dairy Federation, "Caseins and caseinates. Determination of protein content. IDF Stand. 92.” International Dairy Federation, Brussels, Belgium, 1979.

[24] M. N. Vaghela and A. Kilara, "A rapid method for extraction of total lipids from whey protein concentrates and separation of lipid classes with solid phase extraction," Journal of the American Oil Chemists Society, vol. 72, no. 10, pp. 1117-1121, 1995.

[25] Association of the Official Analytical Chemists, Official Methods of Analysis, AOAC, Washington, DC, USA, 15th edition, 1990.

[26] D. C. Montgomery, "Response surface methods and other approaches to process optimization," Design and Analysis of Experiments, Springer, Berlin, Germany, 1997. 
[27] D.-H. Kim, D. Jeong, K.-Y. Song, and K.-H. Seo, "Comparison of traditional and backslopping methods for kefir fermentation based on physicochemical and microbiological characteristics," Lebensmittel-Wissenschaft \& Technologie, vol. 97, pp. 503-507, 2018.

[28] V. L. Singleton and J. A. J. Rossi, "Colorimetry of total phenolics with phosphomolybdic-phosphotungstic acid reagents," American Journal of Enology and Viticulture, vol. 16, pp. 144-158, 1965.

[29] M. Karaaslan, M. Ozden, H. Vardin, and H. Turkoglu, "Phenolic fortification of yogurt using grape and callus extracts," Lebensmittel-Wissenschaft und -Technologie- Food Science and Technology, vol. 44, no. 4, pp. 1065-1072, 2011.

[30] G. Balakrishnan and R. Agrawal, "Antioxidant activity and fatty acid profile of fermented milk prepared by Pediococcus pentosaceus," Journal of Food Science \& Technology, vol. 51, no. 12, pp. 4138-4142, 2014.

[31] B. M. Watts, G. L. Ylimaki, L. E. Jeffery, and L. G. Elias, Basic Sensory Methods for Food Evaluation, pp. 59-100, The International Development Research Center, Ottawa, Canada, 1989.

[32] H. Yaakob, N. R. Ahmed, S. K. Daud, R. A. Malek, and R. A. Rahman, "Optimization of ingredient and processing levels for the production of coconut yogurt using response surface methodology," Food Science and Biotechnology, vol. 21, no. 4, pp. 933-940, 2012.

[33] A. G. Cruz, J. A. F. Faria, E. H. M. Walter et al., "Processing optimization of probiotic yogurt containing glucose oxidase using response surface methodology," Journal of Dairy Science, vol. 93, no. 11, pp. 5059-5068, 2010.

[34] M. Yolmeh and S. M. Jafari, "Applications of response surface methodology in the food industry processes," Food and Bioprocess Technology, vol. 10, no. 3, pp. 413-433, 2017.

[35] C. Messaoud, Y. Zaouali, A. B. Salah, M. L. Khoudja, and M. Boussaid, "Myrtus communis in Tunisia: variability of the essential oil composition in natural populations," Flavour and Fragrance Journal, vol. 20, no. 6, pp. 577-582, 2005.

[36] W. Aidi Wannes and B. Marzouk, "Differences between myrtle fruit parts (Myrtus communis var. italica) in phenolics and antioxidant contents," Journal of Food Biochemistry, vol. 37, no. 5, pp. 585-594, 2013.

[37] C. Messaoud and M. Boussaid, "Myrtus communis berry color morphs: a comparative analysis of essential oils, fatty acids, phenolic compounds, and antioxidant activities," Chemistry and Biodiversity, vol. 8, pp. 300-10, 2011.

[38] S. Hati, S. Vij, B. P. Singh, and S. Mandal, " $\beta$-glucosidase activity and bioconversion of isoflavones during fermentation of soymilk," Journal of the Science of Food and Agriculture, vol. 95, no. 1, pp. 216-220, 2015.

[39] S. G. G. Morais, G. da Silva Campelo Borges, M. Dos Santos Lima, O. Martín-Belloso, and M. Magnani, "Effects of probiotics on the content and bioaccessibility of phenolic compounds in red pitaya pulp," Food Research International (Ottawa, Ont.), vol. 126, Article ID 108681, 2019.

[40] Z. E. Mousavi, S. M. Mousavi, S. H. Razavi, Z. Emam-Djomeh, and H. Kiani, "Fermentation of pomegranate juice by probiotic lactic acid bacteria," World Journal of Microbiology and Biotechnology, vol. 27, no. 1, pp. 123-128, 2011.

[41] N. Sabokbar and F. Khodaiyan, "Total phenolic content and antioxidant activities of pomegranate juice and whey based novel beverage fermented by kefir grains," Journal of Food Science \& Technology, vol. 53, no. 1, pp. 739-747, 2016.

[42] N. Sabokbar, F. Khodaiyan, and M. Moosavi-Nasab, "Optimization of processing conditions to improve antioxidant activities of apple juice and whey based novel beverage fermented by kefir grains," Journal of Food Science \& Technology, vol. 52, pp. 3422-3432, 2015.

[43] J. Gury, L. Barthelmebs, N. P. Tran, C. Diviès, and J.-F. Cavin, "Cloning, deletion, and characterization of PadR, the transcriptional repressor of the phenolic acid decarboxylaseencoding padA gene of Lactobacillus plantarum," Applied and Environmental Microbiology, vol. 70, no. 4, pp. 2146-2153, 2004.

[44] P. Filannino, M. Gobbetti, M. De Angelis, and R. Di Cagno, "Hydroxycinnamic acids used as external acceptors of electrons: an energetic advantage for strictly heterofermentative lactic acid bacteria," Applied and Environmental Microbiology, vol. 80, no. 24, pp. 7574-7582, 2014.

[45] P. Filannino, R. Di Cagno, and M. Gobbetti, "Metabolic and functional paths of lactic acid bacteria in plant foods: get out of the labyrinth," Current Opinion in Biotechnology, vol. 49, pp. 64-72, 2018.

[46] L. Ayed, S. M'hir, and M. Hamdi, "Microbiological, biochemical, and functional aspects of fermented vegetable and fruit beverages," Journal of Chemistry, vol. 2020, Article ID 5790432, 12 pages, 2020.

[47] L. Ayed and M. Hamdi, "Manufacture of a beverage from cactus pear juice using "tea fungus" fermentation," Annals of Microbiology, vol. 65, no. 4, pp. 2293-2299, 2015.

[48] J. A. Curiel, D. Pinto, B. Marzani et al., "Lactic acid fermentation as a tool to enhance the antioxidant properties of Myrtus communis berries," Microbial Cell Factories, vol. 14, no. 1, p. 67, 2015.

[49] L. Ayed, S. Ben Abid, and M. Hamdi, "Development of a beverage from red grape juice fermented with the Kombucha consortium," Annals of Microbiology, vol. 67, no. 1, pp. 111-121, 2016.

[50] F. A. Fiorda, G. V. de Melo Pereira, V. Thomaz-Soccol, A. P. Medeiros, S. K. Rakshit, and C. R. Soccol, "Development of kefir-based probiotic beverages with DNA protection and antioxidant activities using soybean hydrolyzed extract, colostrum and honey," LWT-Food Science and Technology, vol. 68, pp. 690-697, 2016.

[51] J. Hampton, C. Tang, A. J. Subhash, and L. Serventi, “Assessment of pear juice and puree as a fermentation matrix for water kefir," Journal of Food Processing and Preservation, vol. 45 , no. 3 , pp. 1-7, 2020.

[52] B. Hernández-Ledesma, B. Miralles, L. Amigo, M. Ramos, and I. Recio, "Identification of antioxidant and ACE-inhibitory peptides in fermented milk," Journal of the Science of Food and Agriculture, vol. 85, no. 6, pp. 1041-1048, 2005.

[53] D. Sirirat and P. Jelena, "Bacterial inhibition and antioxidant activity of kefir," Biotechnology, vol. 9, no. 3, pp. 332-337, 2010.

[54] S. M’hir, P. Filannino, A. Mejri, A. Z. Alabiden Tlais, R. Di Cagno, and L. Ayed, "Functional exploitation of carob, oat flour, and whey permeate as substrates for a novel kefir-like fermented beverage: an optimized formulation," Foods, vol. 10, p. 294, 2021.

[55] N. P. Mangia, M. A. Murgia, F. Fancello, A. Nudda, and P. Deiana, "Influence of myrtle juice and syrup on microbiological, physicochemical and sensory features of goat's milk yogurt made with indigenous starter culture," Journal of Microbial \& Biochemical Technology, vol. 6, no. 7, pp. 370374, 2014.

[56] H. İ. Öztürk, T. Demirci, and N. Akın, "Production of functional probiotic ice creams with white and dark blue fruits of Myrtus communis: the comparison of the prebiotic 
potentials on Lactobacillus casei 431 and functional characteristics," Lebensmittel-Wissenschaft \& Technologie, vol. 90, pp. 339-345, 2018.

[57] Food and Agriculture Organization of the United Nations, World Health Organization (FAO/WHO), Probiotics in Food: Health and Nutritional Properties and Guidelines for Evaluation, Food and Agriculture Organization of the United Nations: World Health Organization, Rome, Italy, 2006.

[58] A. Koksoy and M. Kilic, "Use of hydrocolloids in textural stabilization of a yoghurt drink, ayran," Food Hydrocolloids, vol. 18, no. 4, pp. 593-600, 2004.

[59] C. Pereira, M. Henriques, M. Henriques, D. Gomes, A. Gomez-Zavaglia, and G. de Antoni, "Novel functional whey-based drinks with great potential in the dairy industry," Food Technology and Biotechnology, vol. 53, no. 3, pp. 307314, 2015.

[60] T. Pinto and A. Vilela, "Healthy drinks with lovely colors: phenolic compounds as constituents of functional beverages," Beverages, vol. 7, no. 1, p. 12, 2021.

[61] S. A. Kabakc1, M. Türkyılmaz, and M. Özkan, "Changes in the quality of kefir fortified with anthocyanin-rich juices during storage," Food Chemistry, vol. 326, Article ID 126977, 2020.

[62] C. P. Champagne, N. J. Gardner, and D. Roy, "Challenges in the addition of probiotic cultures to foods," Critical Reviews in Food Science and Nutrition, vol. 45, no. 1, pp. 61-84, 2005.

[63] C. Wang, Y. Cui, and X. Qu, "Mechanisms and improvement of acid resistance in lactic acid bacteria," Archives of Microbiology, vol. 200, no. 2, pp. 195-201, 2018.

[64] S. Nualkaekul and D. Charalampopoulos, "Survival of Lactobacillus plantarum in model solutions and fruit juices," International Journal of Food Microbiology, vol. 146, no. 2, pp. 111-117, 2011. 